\title{
ВІДГОДІВЕЛЬНІ І М'ЯСНІ ЯКОСТІ МОЛОДНЯКУ СВИНЕЙ РІЗНИХ ГЕНЕАЛОГІЧНИХ ЛІНІЙ ТА ВНУТРІПОРОДНОӤ ДИФЕРЕНЦІАЦІЇ ЗА ДЕЯКИМИ ОЦІНОЧНИМИ ІНДЕКСАМИ
}

\author{
Халак Віктор Іванович \\ кандидат сільськогосподарських наук, ст. науковий співробітник \\ ДУ Інститут зернових культур НААН України \\ ORCID: 0000-0002-4384-6394 \\ E-mail: v16kh91@gmail.com
}

\begin{abstract}
Наведено результати оцінки відгодівельних і м'ясних якостей молодняку свиней великої білої породи різних генеалогічних ліній та внутріпородної дифреренціації за індексом Б. Тайлера, а також економічну ефективність їх використання. Дослідження проведено в умовах ТОВ «Агро-Еліта» Дніпропетровської області, м'ясокомбінату «Дніпро» та лабораторії тваринниитва ДУ Інститут зернових культур НААН. Робота виконана згідно програми наукових досліджень НААН №30 «Свинарство». Контрольну відгодівлю молодняку свиней проводили в умовах господарства згідно «Методики оцінки кнурів і свиноматок за якістю потомства в умовах племінних заводів і племінних репродукторів» (М.Д. Березовський, І.В. Хатько, 2005). Оцінку молодняку свиней за відгодівельними і м'ясними якостями проводили з урахуванням наступних показників: середньодобовий приріст живої маси за період відгодівлі від 30 до 100 ке, вік досягнення живої маси 100 ке, довжина охолодженої туші, товщина шпику на рівні 6-7 грудних хребців, площа «м'язового вічка», маса задньої третини охолодженої півтуші. Комплексну оцінку тварин основного стада проводили за індексом відгодівельних і м'ясних якостей їх потомства (індекс Б. Тайлера) (цит. за П.А. Ващенко, 2019).Встановлено, що молодняк свиней підконтрольного стада за віком досягнення живої маси 100 ке, товщиною шпику на рівні 6-7 грудних хребців та довжиною охолодженої туші переважає мінімальні вимоги класу еліта в середньому на 5,47 \%. Тварини лінії Славутич переважають ровесників ліній Сніжка і Чингіза за середньодобовим приростом живої маси на 1,97-7,00 \%, віком досягнення живої маси 100 кг - 2,974,32 \%, товщиною шпику на рівні 6-7 грудного хребия -10,48-16,14 \%, площею «м'язового вічка» - 10,96-10,69 \%, масою задньої третини охолодженої півтуші - 0,95-2,85 \%, комплексним індексом відгодівельних і м'ясних якостей (індексом $Б$. Тайлера) - 8,47-17,65 \%. Достовірну різницю з імовірністю $P<0,05-0,001$ встановлено між тваринами класу $M^{+}$i $M^{-}$за середньодобовим приростом живої маси за період відгодівлі від 30 до 100 кг (на 33,7- 45,0 г), площею «м'язового вічка» (на 1,0-4,8 см²), комплексним індексом відгодівельних і м'ясних якостей (індексом Б. Тайлера) (на 17,55-43,68 балів). За масою задньої третини охолодженої півтуші молодняк свиней класу $M^{+}$переважав ровесників класу $M^{-}$на 0,6 к己 $(t d=3,52 ; P<0,01)$. Меншими показниками «вік досягнення живої маси 100 ке (на 3,6-10,2 доби) та «товщина шпику на рівні 6-7 хребиів» (на 2,8- 5,9 мм) характеризуються молодняк свиней, у яких комплексний індекс відгодівельних і м'ясних якостей коливався у межах від 174,12 до 193,06 балів. Максимальну прибавку додаткової продукції за показником «середньодобовий приріст живої маси за період відгодівлі від 30 до 100 кг, г»» одержано від молодняку свиней генеалогічної лінії Славутич (+3,22 \%) та клас розподілу за індексом Б. Тайлера $M^{+}(+4,19$ \%). Вартість додаткової продукиії, яку одержують від тварин зазначених груп дорівнює +777,06 - +1011,14 грн. / гол.
\end{abstract}

Ключові слова: молодняк свиней, порода, генеалогічна лінія, відгодівельні і м'ясні якості, оціночний індекс, економічну ефеективність, мінливість, кореляція.

DOI: https://doi.org/10.32845/bsnau.lvst.2020.2.12.

Збільшення виробництва високоякісної свинини обумовлене факторами зовнішнього середовища та генотипом тварин. Частка впливу того чи іншого фактору на фенотиповий прояв кількісної ознаки визначається коефіцієнтом успадкування ( $\left.\mathrm{h}^{2}\right)$. Так, у свиней, даний показник за багатоплідністю, великоплідністю, молочністю і масою гнізда поросят у 60 діб коливається у межах від 4 до 32 \%, відгодівельними якостями молодняку свиней - від 5 до $81 \%$. Максимальні коефіцієнти успадкування встановлено за довжиною охолодженої туші (38-78 \%), товщиною шпику на рівні 6-7 грудних хребців (22-97 \%), площею «м'язового вічка» (10-79 \%) та виходом м'яса у туші (14-71\%).

В зв'язку з інтенсифікацією селекційного процесу в галузі свинарства України, який відбувається з використанням тварин зарубіжних порід важливим завданням для науковців та спеціалістів агроформувань, поряд 3 дослідження рівня адаптації та відтворення поголів'я свиней $\epsilon$ аналіз даних щодо характеру успадкування відгодівельних та мясних якостей тварин різних порід, спеціалізованих типів, генеалогічних ліній і родин, а також пошук ефективних

методів оцінки зазначених груп ознак та їх використання в селекційно-племінній роботі.

Теоретичною основою для проведення досліджень $\epsilon$ наукові праці вітчизняних та зарубіжних вчених [1-9].

Мета роботи - дослідити відгодівельні і м'ясні якості молодняку свиней великої білої породи різних генеалогічних ліній та внутріпородної диференціації за індексом Б. Тайлера, розрахувати економічну ефрективність їх використання.

Матеріал і методика досліджень. Дослідження проведено в умовах ТОВ «Агро-Еліта» Дніпропетровської області, м'ясокомбінату «Дніпро» та лабораторії тваринництва ДУ Інститут зернових культур НААН. Робота виконана згідно програми наукових досліджень НААН №30 «СвинарсTBO».

Об'єктом досліджень був молодняк свиней великої білої породи генеалогічних ліній Чингіза, Сніжка та Славутича. Оцінку молодняку свиней за відгодівельними і м'ясними якостями проводили з урахуванням абсолютних та інтегрованих показників, а саме: середньодобовий приріст живої маси за період відгодівлі від 30 до 100 кг, г, вік досягнення 
живої маси 100 кг, діб, довжина охолодженої туші, см, товщина шпику на рівні 6-7 грудних хребців, мм, площа «м'язового вічка», см², маса задньої третини охолодженої півтуші, кг [10].

Вік досягнення живої маси 100 кг $(1,2)$, комплексний індекс відгодівельних і м'ясних якостей (індекс Б. Тайлера) (3) та економічну ефективність проведених досліджень (4) розраховували за формулами:

якщо жива маса тварини дорівнювала 85-99 ке:

$$
Д_{100}=\left[\left(100 \kappa 2-M_{0}\right) \div \frac{M_{0}-M_{n o}}{Д_{0}-Д_{n o}}\right]+Д_{0} \text {, }
$$

якщо жива маса тварини дорівнювала 101-115 ке:

$$
Д_{100}=Д_{0}-\left[\left(M_{0}-100 \kappa 2\right) \div \frac{M_{0}-M_{n o}}{Д_{0}-Д_{n o}}\right]+Д_{0} \text {, }
$$

де: Д100 - вік досягнення живої маси 100 кг, діб; До вік при останньому зважуванні, діб; Дпо - вік попереднього зважування, діб; Мо - жива маса при останньому зважуванні, кг; $\mathrm{M}_{\text {по }}$ - жива маса при попередньому зважуванні, кг [11];

$$
I_{в}=100+(242 \times K)-(4,13 \times L),
$$

де: Ів - комплексний індекс відгодівельних і м'ясних якостей (індекс Б.Тайлера), бала, К - середньодобовий приріст, кг; L - товщина шпику на рівні 6-7 грудних хребців, мм; 242; 4,13 - постійні коефріцієнти [12];

$$
E=Ц \times \frac{C \times \Pi}{100} \times \pi \times K
$$

де: Е - вартість додаткової продукції, грн.; Ц - заку- півельна ціна одиниці продукції, відповідно до існуючих цін, які діють в Україні; С - середня продуктивність тварин; П середня надбавка основної продукції (\%), яка виражена у відсотках на 1 голову при застосуванні нового і поліпшеного селекційного досягнення порівняно з продуктивністю тварин базового використання; Л - постійний коефіцієнт зменшення результату, який пов'язаний з додатковими витратами на прибуткову продукцію $(0,75) ;$ К - чисельність поголів'я сільськогосподарських тварин нового або поліпшеного селекційного досягнення, голів [13].

Результати досліджень опрацьовано методом варіаційної статистики за методикою Г.Ф. Лакіна [14].

Результати досліджень. Встановлено, що молодняк свиней великої білої породи підконтрольного стада характеризується відносно високими показниками відгодівельних і м'ясних якостей. Так, середньодобовий приріст живої маси тварин за період контрольної відгодівлі дорівнює 619,0-812,5 г, вік досягнення живої маси 100 кг - 173-197 діб, товщина шпику на рівні 6-7 грудного хребця - 22-31 мм, довжина охолодженої туші - 91,0-102,0 см, площа «м'язового вічка» - 28,27-38,80 см², маса задньої третини охолодженої півтуші - 9,8-11,3 кг.

За віком досягнення живої маси 100 кг, товщиною шпику на рівні 6-7 грудного хребця і довжиною охолодженої туші молодняк свиней великої білої породи генеалогічних ліній Чингіза, Сніжка і Славутича належить до класу «еліта» ( табл. 1).

Відгодівельні та м'ясні якості молодняку великої білої породи піддослідної групи

Таблиця 1

\begin{tabular}{|l|c|c|c|c|}
\hline \multicolumn{1}{|c|}{ Показник } & \multicolumn{3}{c|}{ Біометричі показники } \\
\cline { 2 - 5 } Сv & $n$ & $\bar{X} \pm S \bar{x}$ & $\sigma \pm S \sigma$ & $\%$ \\
\hline Середньодобовий приріст живої маси за період відгодівлі від 30 до 100 кг, г & 49 & $710,7 \pm 5,04$ & $35,34 \pm 3,573$ & $4,97 \pm 0,502$ \\
\hline Вік досягнення живої маси 100 кг, дн & 49 & $184,4 \pm 0,83$ & $5,85 \pm 0,591$ & $3,17 \pm 0,320$ \\
\hline Довжина охолодженої туші, см & 49 & $96,2 \pm 0,41$ & $2,87 \pm 0,290$ & $2,98 \pm 0,301$ \\
\hline Товщину шпику на рівні 6-7 грудного хребця, мм & 49 & $26,5 \pm 0,40$ & $2,82 \pm 0,285$ & $10,64 \pm 1,075$ \\
\hline Комплексний індекс відгодівельних і м'ясних якостей (індекс Б.Тайлера), бала & 49 & $162,2 \pm 2,45$ & $17,20 \pm 1.739$ & $10,60 \pm 1,071$ \\
\hline Площа «м'язового вічка», см² & 22 & $34,7 \pm 0,63$ & $2,98 \pm 0,449$ & $8,58 \pm 1,294$ \\
\hline Маса задньої третини охолодженої пів туші, кг & 22 & $10,3 \pm 0,12$ & $0,55 \pm 0,082$ & $5,33 \pm 0,803$ \\
\hline
\end{tabular}

Аналіз результатів досліджень відгодівельних та м'ясних якостей молодняку свиней різних генеалогічних ліній показав, що тварини лінії Славутич переважали ровесників ліній Сніжка і Чингіза за середньодобовим приростом живої маси на 14,5 г (td=1,49; $P>0,05), 51,5$ (td=5,56; $P<0,001)$, віком досягнення живої маси 100 кг - на 5,5 (td=3,92; $P<0,01)$ - 8,1 діб ( $\mathrm{td}=4,00 ; P<0,001)$, товщиною шпику на рівні 6-7 грудного хребця - на 2,8 (td=3,63; $\mathrm{P}<0,01)-4,6$ мм (td=8,28; $\mathrm{P}<0,001)$, площею «м'язового вічка» - на 4,1 ( $\mathrm{td}=2,78$; $\mathrm{P}<0,01)-4,0 \mathrm{~cm}^{2}(\mathrm{td}=5,19 ; \mathrm{P}<0,001)$, масою задньої третини охолодженої півтуші - на 0,1 кг $(\mathrm{td}=0,31 ; \mathrm{P}>0,05)-0,3$ $(\mathrm{td}=1,07 ; \mathrm{P>0}, 05)$, комплексним індексом відгодівельних і м'ясних якостей (індексом Б. Тайлера) - на 15,15 (td=3,51; $\mathrm{P}<0,01)$ - 31,56 бала ( $\mathrm{td}=8,89 ; \mathrm{P}<0,001)$ (табл. 2).
Більшою довжиною охолодженої туші (на 0,1 $(\mathrm{td}=0,09 ; \mathrm{P}>0,05)-2,8 \mathrm{~cm}(\mathrm{td}=3,25 ; \mathrm{P}<0,01)$ характеризувалися тварини ліній Сніжка.

3 урахуванням класу розподілу за комплексним індексом відгодівельних і м'ясних якостей (індексом Б. Тайлера) встановлено, що молодняк свиней класу $\mathrm{M}^{+}$, порівняно 3 ровесниками класу $\mathrm{M}^{0}$ та $\mathrm{M}^{-}$характеризувався більшими показниками середньодобового приросту живої маси за період відгодівлі від 30 до 100 кг (на 33,7 (td=3,44; P<0,01) $45,0$ г (td=5,33; $P<0,001)$, площі «м'язового вічка» (на 1,0 $(\mathrm{td}=0,81)-4,8 \mathrm{~cm}^{2}(\mathrm{td}=3,93 ; \mathrm{P}<0,001)$, комплексного індексу відгодівельних і м'ясних якостей (індекс Б. Тайлера) (на $17,55$ (td=7,59, $\mathrm{P}<0,001)-43,68$ балів ( $\mathrm{td}=20,12 ; \mathrm{P}<0,001)$ та маси задньої третини охолодженої півтуші (на 0,2 (td=0,76; $\mathrm{P}>0,05)-0,6$ кг (td=3,52; $\mathrm{P}<0,01)$ (табл. 3). 
Таблиця 2

Відгодівельні та м'ясні якості молодняку великої білої породи різних генеалогічних ліній

\begin{tabular}{|c|c|c|c|c|}
\hline \multirow{2}{*}{ Показник } & \multirow{2}{*}{$\begin{array}{c}\text { Біометричні } \\
\text { показники }\end{array}$} & \multicolumn{3}{|c|}{ Генеалогічна лінія } \\
\hline & & Чингіз & Сніжок & Славутич \\
\hline \multirow{4}{*}{$\begin{array}{l}\text { Середньодобовий приріст живої маси за } \\
\text { період відгодівлі від } 30 \text { до } 100 \text { кг, г }\end{array}$} & $\mathrm{n}$ & 18 & 16 & 15 \\
\hline & $\bar{X} \pm S \bar{x}$ & $682,5 \pm 6,96$ & $719,5 \pm 7,51$ & $734,0 \pm 6,11$ \\
\hline & $\sigma \pm S \sigma$ & $29,55 \pm 4,925$ & $30,04 \pm 6,114$ & $23,68 \pm 4,329$ \\
\hline & $\mathrm{Cv} \pm \mathrm{Sc}_{\mathrm{v}}, \%$ & $4,32 \pm 0,720$ & $4,17 \pm 0,738$ & $3,22 \pm 0,588$ \\
\hline \multirow{3}{*}{ Вік досягнення живої маси 100 кг, дн. } & $\bar{X} \pm S \bar{x}$ & $187,4 \pm 1,62$ & $184,8 \pm 0,70$ & $179,3 \pm 1,22$ \\
\hline & $\sigma \pm \mathrm{S} \sigma$ & $6,87 \pm 1,145$ & $2,80 \pm 0,485$ & $4,73 \pm 0,864$ \\
\hline & $\mathrm{Cv}_{\mathrm{N}} \mathrm{Sc}_{\mathrm{v}}, \%$ & $3,67 \pm 0,611$ & $1,51 \pm 0,267$ & $2,63 \pm 0,480$ \\
\hline \multirow{3}{*}{ Довжина охолодженої туші, см } & $\bar{X} \pm S \bar{x}$ & $94,5 \pm 0,50$ & $97,3 \pm 0,70$ & $97,2 \pm 0,74$ \\
\hline & $\sigma \pm S \sigma$ & $2,14 \pm 0,356$ & $2,82 \pm 0,499$ & $2,88 \pm 0,526$ \\
\hline & $\mathrm{Cv}_{ \pm} \pm \mathrm{Sc}_{\mathrm{v}}, \%$ & $2,26 \pm 0,376$ & $2,89 \pm 0,511$ & $2,96 \pm 0,541$ \\
\hline \multirow{3}{*}{$\begin{array}{l}\text { Товщину шпику на рівні 6-7 грудного } \\
\text { хребця, мм }\end{array}$} & $\bar{X} \pm S \bar{x}$ & $28,5 \pm 0,46$ & $26,7 \pm 0,67$ & $23,9 \pm 0,40$ \\
\hline & $\sigma \pm S \sigma$ & $1,87 \pm 0,311$ & $2,64 \pm 0,467$ & $1,57 \pm 0,287$ \\
\hline & $\mathrm{Cv} \pm \mathrm{Sc}_{\mathrm{v}}, \%$ & $6,56 \pm 1,093$ & $9,88 \pm 1,748$ & $6,56 \pm 1,199$ \\
\hline \multirow{4}{*}{$\begin{array}{l}\text { Комплексний індекс відгодівельних і } \\
\text { м'ясних якостей (індекс Б.Тайлера), } \\
\text { балів }\end{array}$} & $\lim$ & $126,43-170,89$ & $134,94-183,28$ & $168,18-205,76$ \\
\hline & $\bar{X} \pm S \bar{x}$ & $147,23 \pm 2,395$ & $163,64 \pm 3,421$ & $178,79 \pm 2,626$ \\
\hline & $\sigma \pm S \sigma$ & $10,16 \pm 1,693$ & $13,68 \pm 2,421$ & $10,17 \pm 1,859$ \\
\hline & $\mathrm{CV}_{ \pm} \pm \mathrm{Sc}_{\mathrm{v}}, \%$ & $6,90 \pm 1,150$ & $8,35 \pm 1,477$ & $5,59 \pm 1,021$ \\
\hline \multirow{4}{*}{ Площа «м'язового вічка», см² } & $\mathrm{n}$ & 8 & 7 & 7 \\
\hline & $\bar{X} \pm S \bar{x}$ & $33,4 \pm 0,53$ & $33,3 \pm 1,36$ & $37,4 \pm 0,57$ \\
\hline & $\sigma \pm S \sigma$ & $1,49 \pm 0,372$ & $3,61 \pm 0,965$ & $1,52 \pm 0,267$ \\
\hline & $\mathrm{Cv}_{\mathrm{N}} \mathrm{Sc}_{\mathrm{v}}, \%$ & $4,46 \pm 1,115$ & $10,84 \pm 2,898$ & $4,07 \pm 1,088$ \\
\hline \multirow{3}{*}{$\begin{array}{l}\text { Мaca задньої третини охолодженої } \\
\text { напівтуші, кг }\end{array}$} & $\bar{X} \pm S \bar{x}$ & $10,2 \pm 0,17$ & $10,4 \pm 0,23$ & $10,5 \pm 0,23$ \\
\hline & $\sigma \pm S \sigma$ & $0,50 \pm 0,125$ & $0,57 \pm 0,152$ & $0,61 \pm 0,163$ \\
\hline & $\mathrm{Cv} \pm \mathrm{Sc}_{\mathrm{v}}, \%$ & $4,90 \pm 1,225$ & $5,48 \pm 1,465$ & $5,80 \pm 1,550$ \\
\hline
\end{tabular}

Відгодівельні та м'ясні якості молодняку великої білої породи різних класів розподілу за комплексним індексом відгодівельних і м'ясних якостей, $(\bar{X} \pm 0,67 \sigma)$

\begin{tabular}{|c|c|c|c|c|}
\hline \multirow{2}{*}{ Показник } & \multirow{2}{*}{$\begin{array}{c}\text { Біометричні } \\
\text { показники }\end{array}$} & \multicolumn{3}{|c|}{ Клас розподілу } \\
\hline & & $\mathrm{M}^{+}$ & $\mathrm{M}^{0}$ & $\mathrm{M}^{-}$ \\
\hline \multirow{4}{*}{$\begin{array}{l}\text { Середньодобовий приріст живої маси } \\
\text { за період відгодівлі від } 30 \text { до } 100 \text { кг, г }\end{array}$} & $\mathrm{n}$ & 15 & 19 & 15 \\
\hline & $\bar{X} \pm S \bar{x}$ & $741,4 \pm 5,38$ & $707,7 \pm 8,19$ & $696,4 \pm 6,50$ \\
\hline & $\sigma \pm S \sigma$ & $20,87 \pm 3,815$ & $35,70 \pm 5,795$ & $25,18 \pm 4,603$ \\
\hline & $\mathrm{CV} \pm \mathrm{Sc}_{\mathrm{v}}, \%$ & $2,81 \pm 0,513$ & $5,04 \pm 0,818$ & $3,61 \pm 0,659$ \\
\hline \multirow{3}{*}{ Вік досягнення живої маси 100 кг, дн } & $\bar{X} \pm S \bar{x}$ & $179,8 \pm 1,22$ & $183,4 \pm 1,03$ & $190,0 \pm 0,88$ \\
\hline & $\sigma \pm S \sigma$ & $4,75 \pm 0,868$ & $4,52 \pm 0,733$ & $3,43 \pm 0,627$ \\
\hline & $\mathrm{Cv}_{\mathrm{NSC}}, \%$ & $2,64 \pm 0,482$ & $2,46 \pm 0,399$ & $1,80 \pm 0,329$ \\
\hline \multirow{3}{*}{ Довжина охолодженої туші, см } & $\bar{X} \pm S \bar{x}$ & $97,0 \pm 0,59$ & $97,4 \pm 0,71$ & $94,4 \pm 0,52$ \\
\hline & $\sigma \pm S \sigma$ & $2,31 \pm 0,422$ & $3,09 \pm 0,501$ & $2,02 \pm 0,369$ \\
\hline & $\mathrm{CV}_{\mathrm{NSC}}, \%$ & $2,38 \pm 0,435$ & $3,17 \pm 0,514$ & $2,13 \pm 0,389$ \\
\hline \multirow{3}{*}{$\begin{array}{l}\text { Товщину шпику на рівні 6-7 грудного } \\
\text { хребция, мм }\end{array}$} & $\bar{X} \pm S \bar{x}$ & $23,6 \pm 0,39$ & $26,4 \pm 0,40$ & $29,5 \pm 0,41$ \\
\hline & $\sigma \pm S \sigma$ & $1,54 \pm 0,281$ & $1,74 \pm 0,282$ & $1,59 \pm 0,290$ \\
\hline & $\mathrm{CV}_{ \pm} \pm \mathrm{Sc}_{\mathrm{v}}, \%$ & $6,52 \pm 1,191$ & $6,59 \pm 1,069$ & $5,38 \pm 0,983$ \\
\hline \multirow{4}{*}{$\begin{array}{l}\text { Комплексний індекс відгодівельних і } \\
\text { м'ясних якостей (індекс Б.Тайлера), } \\
\text { бала }\end{array}$} & $\lim$ & $174,12-193,06$ & $149,40-173,41$ & $125,39-146,45$ \\
\hline & $\bar{X} \pm S \bar{x}$ & $181,71 \pm 1,555$ & $164,16 \pm 1,720$ & $138,03 \pm 1,525$ \\
\hline & $\sigma \pm S \sigma$ & $6,02 \pm 1,100$ & $7,50 \pm 1,217$ & $5,90 \pm 1,076$ \\
\hline & $\mathrm{Cv}_{ \pm} \pm \mathrm{Sc}_{\mathrm{v}}, \%$ & $3,31 \pm 0,605$ & $4,56 \pm 0,740$ & $4,27 \pm 0,780$ \\
\hline \multirow{4}{*}{ Площа «м'язового вічка», см² } & $\mathrm{n}$ & 6 & 9 & 7 \\
\hline & $\bar{X} \pm S \bar{x}$ & $36,9 \pm 0,81$ & $35,9 \pm 0,92$ & $32,1 \pm 0,92$ \\
\hline & $\sigma \pm S \sigma$ & $1,98 \pm 0,361$ & $2,78 \pm 0,451$ & $2,45 \pm 0,447$ \\
\hline & $\mathrm{CV}_{ \pm} \pm \mathrm{Sc}_{\mathrm{v}}, \%$ & $5,36 \pm 0,979$ & $7,74 \pm 1,256$ & $7,63 \pm 1,394$ \\
\hline \multirow{3}{*}{$\begin{array}{l}\text { Маса задньої третини охолодженої пів } \\
\text { туші, кг }\end{array}$} & $\bar{X} \pm S \bar{x}$ & $10,6 \pm 0,14$ & $10,4 \pm 0,22$ & $10,0 \pm 0,10$ \\
\hline & $\sigma \pm S \sigma$ & $0,35 \pm 0,063$ & $0,68 \pm 0,110$ & $0,24 \pm 0,043$ \\
\hline & $\mathrm{Cv} \pm \mathrm{Sc}_{\mathrm{v}}, \%$ & $3,30 \pm 0,603$ & $6,53 \pm 1,060$ & $2,40 \pm 0,438$ \\
\hline
\end{tabular}

Тварини, у яких комплексний індекс відгодівельних і м'ясних якостей коливався у межах від 174,12 до 193,06 бала (молодняк свиней класу $\mathrm{M}^{+}$) характеризувалися меншими показниками «вік досягнення живої маси 100 кг (на 3,6 $(\mathrm{td}=2,26 ; \mathrm{P}<0,05)-10,2$ доби $(\mathrm{td}=6,80 ; \mathrm{P}<0,05))$ та «товщина шпику на рівні 6-7 хребців» (на 2,8 (td=5,09; $P<0,001)$ - 5,9 Mм (td=10,53; $P<0,001)$.

Результати розрахунку економічної есрективності проведених досліджень наведено в таблиці 4. 
Економічна ефективність результатів досліджень

\begin{tabular}{|c|c|c|c|c|}
\hline $\begin{array}{c}\text { Група } \\
\text { (генеалогічна лінія), } \\
\text { клас розподілу за } \\
\text { індексом Б. Тайлера }\end{array}$ & $\mathrm{n}$ & $\begin{array}{c}\text { Середньодобовий приріст } \\
\text { живої маси за період відгодівлі } \\
\text { від } 30 \text { до } 100 \text { кг, г }\end{array}$ & $\begin{array}{c}\text { Прибавка додаткової } \\
\text { продукції, \% }\end{array}$ & $\begin{array}{c}\text { Вартість додаткової продукції, } \\
\text { грн./гол. }{ }^{*}\end{array}$ \\
\hline Загальна вибірка & 49 & $710,3 \pm 5,04$ & - & - \\
\hline \multicolumn{5}{|c|}{ генеалогічна лінія } \\
\hline Чингіз & 18 & $682,5 \pm 6,96$ & $-3,91$ & $-943,57$ \\
\hline Сніжок & 16 & $719,5 \pm 7,51$ & $+1,27$ & $+306,48$ \\
\hline Славутич & 15 & $734,0 \pm 6,11$ & $+3,22$ & $+777,06$ \\
\hline \multicolumn{5}{|c|}{ клас розподілу за індексом Б. Тайлера } \\
\hline $\mathrm{M}^{-}$ & 15 & $696,4 \pm 6,50$ & $-1,95$ & $-470,58$ \\
\hline $\mathrm{M}^{0}$ & 19 & $707,7 \pm 8,19$ & $-0,36$ & $-86,87$ \\
\hline $\mathrm{M}^{+}$ & 15 & $741,4 \pm 5,38$ & $+4,19$ & $+1011,14$ \\
\hline
\end{tabular}

Примітка: * - ціна реалізації молодняку свиней на дату проведення досліджень дорівнювала 45,3 грн. за 1 ке живої маси

Встановлено, що максимальну прибавку додаткової продукції за показником «середньодобовий приріст живої маси за період відгодівлі від 30 до 100 кг, г»» одержано від молодняку свиней генеалогічної лінії Славутич $(+3,22 \%)$ та клас розподілу за індексом Б. Тайлера $\mathrm{M}^{+}(+4,19 \%)$. Вартість додаткової продукції, яку одержують від тварин зазначених груп дорівнює +777,06 - +1011,14 грн. / гол.

\section{Висновки:}

1. Молодняк свиней великої білої породи підконтрольного стада характеризується високими показниками відгодівельних та м'ясних якостей, а за віком досягнення живої маси 100 кг, товщиною шпику на рівні 6-7 грудних хребців та довжиною охолодженої туші переважають мінімальні вимоги класу еліта в середньому на $5,47 \%$.

2. Встановлено, що молодняк свиней лінії Славутич переважав ровесників ліній Сніжка і Чингіза за середньодобовим приростом живої маси на 1,97-7,00 \%, віком досягнення живої маси 100 кг - 2,97-4,32 \%, товщиною шпику на рівні 6-7 грудного хребця $-10,48-16,14 \%$, площею «м'язового вічка» - 10,96-10,69 \%, масою задньої третини охолодженої півтуші - 0,95-2,85 \%, комплексним індексом відгодівельних і м'ясних якостей (індексом Б. Тайлера) $8,47-17,65 \%$.

3. Достовірну різницю 3 імовірністю $\mathrm{P}<0,05-0,001$ встановлено між тваринами класу $\mathrm{M}^{+} \mathrm{i} \mathrm{M}^{-}$за середньодобовим приростом живої маси за період відгодівлі від 30 до 100 кг (на 33,7- 45,0 г), площею «м'язового вічка» (на 1,0-4,8 $\mathrm{cm}^{2}$ ), комплексним індексом відгодівельних і м'ясних якостей (індексом Б. Тайлера) (на 17,55-43,68 балів). За масою задньої третини охолодженої півтуші молодняк свиней класу $\mathrm{M}^{+}$переважав ровесників класу $\mathrm{M}^{-}$на 0,6 кг (td=3,52; $\left.\mathrm{P}<0,01\right)$.

4. Меншими показниками «вік досягнення живої маси 100 кг (на 3,6-10,2 доби) та «товщина шпику на рівні 6-7 хребців» (на 2,8- 5,9 мм) характеризуються молодняк свиней, у яких комплексний індекс відгодівельних і м'ясних якостей коливався у межах від 174,12 до 193,06 балів.

5. Максимальну прибавку додаткової продукції за показником «середньодобовий приріст живої маси за період відгодівлі від 30 до 100 кг, г»» одержано від молодняку свиней генеалогічної лінії Славутич $(+3,22 \%)$ та клас розподілу за індексом Б. Тайлера $\mathrm{M}^{+}(+4,19 \%)$. Вартість додаткової продукції, яку одержують від тварин зазначених груп дорівнює від $+777,06$ до +1011,14 грн. / гол.

\section{Список використаної літератури:}

1.Використання математичних функцій для визначення закономірностей росту та прогнозування живої маси свиней / В. П. Коваленко та ін. Таврійський науковий вісник. Херсон., 2012. Вип. 78. Ч. 2. С. 190-195.

2. Лобан Н. А. Селекция на повышение продуктивних качеств свиней белорусской крупной белой породы с использованием маркерних генов. Зоотехническая наука Белоруси: сб. науч. тр. Жодино, 2020. Т. 55. Ч. 1. С. $145-156$.

3. Лобан Н. А. Система селекционно-генетических методов оценки откормочных и мясных качеств свиней. Свинарство. Міжвідомчий темат. наук. зб. Інституту свинарства і АПВ НААН. Полтава, 2014. Вип. 65. С. 69-75.

4.Гришина Л. П. Використання математичного моделювання для прогнозування живої маси молодняку свиней різних генотипів. Свинарство. Міжвідомчий темат. наук. зб Інституту свинарства і АПВ НААН. Полтава, 2014. Вип. 65. С. 101-108.

5. A mathematical procedure for estimating animal growth and body composition / T. C. Bridges et al. Trans. ASAE. St. Joseph. Mich. 1986. V. 29 № 5. P. 1342-1347.

6. Minkema A. An experiment on crossbreeding between Holstein-Friesian bulls and Dutch Friesian coms. Proc.Work.Symp.Breed Evolution and Crossing Experiment in Form Animals. Zeist, 1974. P. 207-216.

7. Сучасні методики досліджень у свинарстві / В. П. Рибалко та ін. Полтава, 2005. 228 с.

8. Effect of blood serum enzymes on meat qualities of piglet productivity / V. Khalak et al. Ukrainian Journal of Ecology. 2020. № 10 (1), Р. 158-161. (doi: 10.15421/2020_25).

9.Халак В. І. Біохімічні показники сироватки крові та їх зв'язок з відгодівельними і м'ясними якостями та фізикохімічними властивостями найдовшого м'яза спини молодняку свиней великої білої породи. Зернові культури. Дніпро: «Нова ідеологія», 2019. Том 3. № 2. С. 361-368.

10. Березовський М. Д., Хатько І. В. Методики оцінки кнурів і свиноматок за якістю потомства в умовах племінних заводів і племінних репродукторів. Сучасні методики досліджень у свинарстві. Полтава, 2005. С. 32-37.

11. Інструкція з бонітування свиней. Інструкція з ведення племінного обліку у свинарстві. Київ: Видавничо - полігра- 
фічний центр «Київський університет», 2003. 64 с.

12. Ващенко П. А. Прогнозування племінної цінності свиней на основі лінійних моделей селекційних індексів та ДНКмаркерів: автореф. дис.. на здобуття наук. ступеня д-ра с.-г. наук : спец. 06.02 .01 «Розведення та селекція тварин». Миколаїв, 2019. 43 C.

13. Методика определения экономической эффективности использования в сельском хозяйстве результатов научно-исследовательских работ, новой технологии, изобретений и рационализаторских предложений. Москва: ВАИИПИ, 1983. $149 \mathrm{c}$.

14. Лакин Г. Ф. Биометрия. Москва: Высшая школа, 1990. 352 с.

\section{References:}

1. Kovalenko V.P.,. Stryzhak T.A, Khvatov F.I. 2012. Vykorystannya matematychnykh funktsiy dlya vyznachennya zakonomirnostey rostu ta prohnozuvannya zhyvoyi masy svyney [The use of mathematical functions to determine the patterns of growth and forecasting of live weight of pigs] Tavriyskyy naukovyy visnyk., vol. 78, p. 2. pp. 190-195.

2.Loban N.A. 2020. Selektsiya na povysheniye produktivnikh kachestv sviney belorusskoy krupnoy beloy porody $s$ ispol'zovaniyem markernikh genov. [Breeding to improve the productive qualities of pigs of the Belarusian Large White breed using marker genes] Zootekhnicheskaya nauka Belorusi: sb. nauch. tr. Zhodino,. vol. 55.p.1. pp. 145-156.

3. Loban N.A. 2014. Sistema selektsionno-geneticheskikh metodov otsenki otkormochnykh i myasnykh kachestv sviney [System of selection and genetic methods for assessing the fattening and meat qualities of pigs] Svinarstvo. Mízhvídomchiy tematichniy naukoviy zbyrnik Ínstitutu svinarstva í APV NAAS. - issue 65. pp. 69-75.

4. Hryshyna L.P. 2014. Vykorystannya matematychnoho modelyuvannya dlya prohnozuvannya zhyvoyi masy molodnyaku svyney riznykh henotypiv [The use of mathematical modeling for predicting the live weight of young pigs of different genotypes] Svynarstvo. Mizhvidomchyy tematychnyy naukovyy zbirnyk Instytutu svynarstva i APV NAAS. - issue 65. Pp. 101-108.

5. Bridges T.C. A mathematical procedure for estimating animal growth and body composition / T.C.Bridges, L.W.Turner, E.M. Smith [e.a.].- Trans. ASAE. St. Joseph. Mich. - 1986. - V.29. - №5. P.1342-1347.

6. Minkema A. An experiment on crossbreeding between Holstein-Friesian bulls and Dutch Friesian coms / A. Minkema // Proc.Work.Symp.Breed Evolution and Crossing Experiment in Form Animals. - Zeist, 1974. - pp. 207-216.

7.. Rybalko V.P,. Berezovskyy M.D,. Bohdanov H.A. 2005. Suchasni metodyky doslidzhen u svynarstvi [Modern research methods in pig breeding]. Poltava.

8. Khalak, V., Gutyj, B., Bordun, O., Ilchenko, M., Horchanok, A. Effect of blood serum enzymes on meat qualities of piglet productivity. Ukrainian Journal of Ecology, 10 (1), (2020). 158-161. (doi: 10.15421/2020_25).

9. Khalak V.I. 2019. Biokhimichni pokaznyky syrovatky krovi ta yikh zv'yazok z vidhodivelnymy i myasnymy yakostyamy ta fizyko-khimichnymy vlastyvostyamy naydovshoho myaza spyny molodnyaku svyney velykoyi biloyi porody [Biochemical parameters of blood serum and their relationship with fattening and meat qualities and physicochemical properties of the longest back muscle of young pigs of large white breed]. Zernovi kultury. Vol. 3. no.2. pp. 361-368.

10. Berezovskyy M.D., Khatko I.V. 2005. Metodyky otsinky knuriv i svynomatok za yakistyu potomstva v umovakh pleminnykh zavodiv i pleminnykh reproduktoriv [Methods of evaluation of boars and sows by the quality of offspring in the conditions of breeding plants and breeding breeders] Suchasni metodyky doslidzhen u svynarstvi. pp. 32-37.

11. Instruktsiya z bonituvannya svyney. Instruktsiya z vedennya pleminnoho obliku u svynarstvi. 2003 [Instructions for grading pigs. Instructions for keeping breeding records in pig breeding] «Kyyivskyy universytet»

12. Vashchenko P.A. 2019. Prohnozuvannya pleminnoyi tsinnosti svyney na osnovi liniynykh modeley selektsiynykh indeksiv ta DNK-markeriv [Prediction of breeding value of pigs based on linear models of selection indices and DNA markers]: avtoref. dys.. na zdobuttya nauk. stupenya d-ra s.-h. nauk : spets. 06.02 .01 «Rozvedennya ta selektsiya tvaryn». Mykolayiv.

13. Metodika opredeleniya ekonomicheskoy effektivnosti ispol'zovaniya v sel'skom khozyaystve rezul'tatov nauchnoissledovatel'skikh rabot, novoy tekhnologii, izobreteniy i ratsionalizatorskikh predlozheniy. 1983 [Methods for determining the economic efficiency of the use in agriculture of the results of scientific research, new technology, inventions and rationalization proposals]..- M.: VAIIPI.

14. Lakin G.F. 1990. Biometriya. [Biometrics], M.: Vysshaia shkola. P. 352.

Khalak Victor Ivanovich, Ph.D. of Agricultural Sciences, Art. Researcher, SI Institute of Grain Crops NAAS of Ukraine Fattening and meat qualities of young pigs of different genealogical lines and inbreed differentiation according to some evaluators

The results of evaluation of fattening and meat qualities of young pigs of large white breed of different genealogical lines and intrabreed differentiation according to the B. Tyler index, as well as the economic efficiency of their use are presented. The study was conducted in the conditions of «Agro-Elita» LLC, Dnipropetrovsk region, «Dnipro» meat-packing plant and livestock laboratory of the Institute of Grain Crops of NAAS. The work was performed according to the research program of NAAS №30 "Pig breeding". Control fattening of young pigs was carried out in the farm according to the "Methods for assessing boars and sows by the quality of offspring in breeding plants and breeding breeders" (M.D. Berezovsky, I.V. Khat'ko, 2005). Evaluation of young pigs for fattening and meat qualities was carried out taking into account the following indicators: average daily live weight gain for the period of fattening from 30 to $100 \mathrm{~kg}$, age of live weight $100 \mathrm{~kg}$, length of chilled carcass, fat thickness at 6-7 thoracic vertebrae, the area of the "muscle eye", the mass of the posterior third of the cooled carcass. Comprehensive assessment of animals of the main herd was performed according to the index of fattening and meat qualities of their offspring (B. Tyler index) (quoted by P.A. Vashchenko, 2019). It was found that young pigs of the controlled herd at the age of $100 \mathrm{~kg}$, fat thickness at the level of 6-7 thoracic vertebrae and the length of Вісник Сумського національного аграрного університету 
the chilled carcass exceed the minimum requirements of the elite class by an average of $5.47 \%$. Animals of the Slavutych line outnumber their Snizhka and Chingiza peers in terms of average daily live weight gain by 1.97-7.00\%, age of $100 \mathrm{~kg}$ live weight 2.97-4.32\%, fat thickness at the level of 6-7 thoracic vertebra - 10.48-16.14\%, the area of the "muscle cell" - 10.96-10.69\%, the weight of the rear third of the cooled carcass - 0.95-2.85\%, a comprehensive index of fattening and meat qualities (B. Tyler index) 8.47-17.65\%. A significant difference with a probability of $P<0.05-0.001$ was found between animals of class $M+$ and $M-$ on the average daily gain of live weight during the period of fattening from 30 to $100 \mathrm{~kg}$ (33.7-45.0 g), the area of «muscle eyes» (by 1.0 $4.8 \mathrm{~cm}^{2}$ ), complex index of fattening and meat qualities (B. Tyler index) (by 17.55-43.68 points). By weight of the rear third of the cooled carcass, young pigs of class $M+$ outperformed peers of class $M-$ by $0.6 \mathrm{~kg}(\mathrm{td}=3.52 ; P<0.01)$. Lower indicators of "age of live weight of $100 \mathrm{~kg}$ (3.6-10.2 days) and "fat thickness at the level of 6-7 vertebrae"(2.8-5.9 mm) are characterized by young pigs with a complex index fattening and meat qualities ranged from 174.12 to 193.06 points. The maximum increase in additional products on the indicator "average daily live weight gain for the period of fattening from 30 to $100 \mathrm{~kg}, \mathrm{~g}$ " "was obtained from young pigs of the Slavutych genealogical line (+3.22\%) and the distribution class according to B. Tyler's index M+ (+4,19\%). The cost of additional products received from animals of these groups is $+777.06-+1011.14 \mathrm{UAH} / \mathrm{head}$.

Key words: young pigs, breed, genealogical line, fattening and meat qualities, evaluation index, economic efficiency, variability, correlation.

Дата надходження до редакції: 04.09.2020 р. 